\title{
PERSONAL MATURITY AS A COMPONENT OF PERSONAL COMPETENCE OF A SPECIAL EDUCATION TEACHER
}

\author{
Ekaterina Kovalevskaya \\ Department of General and Social Psychology Pskov State University
}

\begin{abstract}
The article is a review of research of personal competence of professionals working with children with special health opportunities. The article describes the results of the expert survey, which was conducted in order to determine personality traits that are important for professional defectologists. The correlation is established between the personal competence and personal maturity. Personal maturity is a condition for the effective and successful implementation of the activity of a special education teacher. Personal maturity is a manifestation of directedness of the personality, which has developed properties.
\end{abstract}

Keywords. Activity, creativity, directedness, personal maturity, personality traits, property, social interest, the desire for self-improvement, the pursuit of creativity

\section{Introduction}

This article was written using the results obtained in the dissertation research on "Psychological conditions of formation of personal directedness in the educational environment of a higher educational institution."

Profession of a special education teacher is responsible and meaningful to society. This specialist provides education to children with special health opportunities.

Professional activities of defectologists extends beyond the traditional teaching activities, working closely with various social, educational, rehabilitation, consultative - diagnostic, psychotherapeutic, correctional and other activities, which are aimed at one goal - to help a person with disabilities in the life of their social adaptation and integration.

All this makes special demands on his personal competence, including humanistic orientation towards children and the desire for self - development.

\section{Materials and Results of Research}

The purpose of the present study was to establish indicators of personal competence of a special education teacher, which are the most important for the successful and effective implementation of their professional activity, and identify methods for their formation and development.

To realize this goal we used the method expert survey. The experts are the leading educational psychologists, defectologists, correctional teachers, psychiatrists Pskov, Russia (12 persons). Their experience of working with children with special health needs ranged from 8 to 20 years ( 6 persons) and 21 to 40 years (6 persons). 
We offered them to write quality professionals working with children with special health opportunities, which, in their opinion, are relevant to the success of this activity. In addition, each quality should be evaluated on a 10-point scale, illustrating the magnitude of its importance for the special educator profession.

Obtaining lists of qualities include not only personal characteristics, but also professional skills, such as "the ability to be attentive to the children," "the ability to apply the studied material is interesting," "be a good psychologist," etc. These skills are not subjected to further analysis in connection with the fact that they relate to professional competence, not to personal competence. Personal qualities, called experts have been content analysis. As a result of the 10 categories were identified personal qualities defectologist.

o The desire for self-development, self-improvement (this group were combined qualities of "desire to develop themselves," "desire to raise the professional level", "self-education", *"desire to get a new experience," etc.);

o Positive thinking (some of the qualities mentioned by experts, "optimism", "ability to emphasize the advantages of the child", "the ability to support the child in a situation of failure," "humanistic beliefs", etc.);

o Activity (this group includes such personal qualities as "Active", "initiative", "passion for work", etc.);

o The desire for creativity ("smart idea", "creative approach to learning", "creativity", etc.);

o Psychological independence ("independence", "ability to defend its position," " lack subjective assessments of children," etc.);

o Awareness of the purposes and meaning of life ("mind the purposes of professional activity", "Purposeful Actions ", etc.);

o Social interest ("the desire to help other people," "altruism", "tolerance for other people," etc.);

o Availability of life philosophy ("realistic view of the world and themselves," "humanistic attitude to children," "the existing system of beliefs," etc.);

o Spontaneous behavior ("flexible behavior," "ease of orientation in the situation," "ease of communication with children," etc.);

o A variety of interests ("versatile person", "passion and enthusiasm", etc.).

Table 1 shows the results of analysis of the importance of these categories of personal qualities for professional special education teachers, according to experts.

To clarify the role of these personal characteristics for the successful and effective implementation of professional defectologist with experts were interviewed. 
Table 1.

Personal characteristics included in the personal competence of a special education teacher (results of the expert survey)

\begin{tabular}{|c|c|}
\hline The indicator of personal maturity & $\begin{array}{c}\text { The number of experts (\%) reporting the } \\
\text { highest value of the indicator }\end{array}$ \\
\hline $\begin{array}{c}\text { The desire for self-development, self- } \\
\text { improvement }\end{array}$ & 900 \\
\hline Positive thinking & 83 \\
\hline Activity & 83 \\
\hline The desire for creativity & 58 \\
\hline Psychological independence & 50 \\
\hline Awareness of the purposes and meaning of life & 50 \\
\hline Social interest & 42 \\
\hline Availability of life philosophy & 33 \\
\hline Spontaneous behavior & 33 \\
\hline A variety of interests & \\
\hline
\end{tabular}

According to experts, the most important personal qualities for the successful and effective implementation of professional defectologist, are the personal qualities that are included in the category of "the desire for self-development, self-improvement." In their reviews, working with children with special health opportunities, poses new professional challenges and problems, which require not only the development of professional skills, but also the development of the self. Especially important are such personal traits as conscientiousness, responsibility, altruism, tolerance.

Category of "positive thinking" is in second place in the ranking. According to the experts, positive thoughts and ideas are always a positive emotional response in children with special abilities. Therefore, the defectologist, formed to take the task of remedial must formulate matching motivators that will stimulate activity in children.

In third place in the ranking of the most important indicators of personal professional competence for professionals working with children with special health opportunities are qualities of the categories of "activity" and "the desire to be creative." The experts noted that the activity of students is important to the success of any learning process, including of special correctional training. Take into account the peculiarities of the children, which cause difficulties in the implementation of the assigned tasks. Therefore leading role defectologist is always the first priority. Special education teacher himself must be active in order to direct and control the activities of children. The importance of striving 
for creativity is the creative approach to work makes the operation unique, diverse, open new aspects in consideration of everyday events and things.

According to experts of personal competence indicators, which are included in the category of "spontaneous behavior" and " variety of interests " are the least important for the successful and effective implementation of professional specialists who work with children with special health opportunities. Of course, these characteristics are important for defectologists. Spontaneity of behavior helps to flexibly respond to difficult situations when dealing with these children. Variety of interests allows diversifying the forms and content of the process of special rehabilitative training. But still, these personal characteristics are inferior compared to those described above.

Having analyzed by an expert survey quality categories, as well as a theoretical overview of psychological and educational literature, we assumed that all these qualities are characteristic of a mature personality.

E.A. Sergienko (2007) defines psychological maturity of personality as a "continuum of personality harmonization tasks and integrative capacity of the subject". Personal maturity allows the subject to act in accordance with their life meaning and purpose, needs, individual characteristics.

N.E. Harlamenkova (2007) also considers that the spontaneity of behavior is an indicator of personal maturity. Spontaneous behavior determined by the level of integration of identity, the degree of internalization of ethical values, motivation and coherent internal control of behavior.

According to most authors awareness and maturity of need-motivational sphere plays a key role in the process of personal development. These researchers believe that the motives and needs are structural components of the directedness of the personality. According A.A. Rean (2002), a fundamental property of a mature personality is the need for self-development, self-improvement. One way to achieve personal maturity, according to the authors, is creativity. This position is shared by Adam D. Galinsky and William W. Maddux (2009). They report the results of their research, according to which personalities, who are actively engaged in creative activities, are more energetic, internally motivated, confident, etc.

G. Allport (2002) identified criteria personal maturity: a variety of independent interest, expansion of the "Self", to protect the interests of others, not selfishness, the formation of the outlook, active mastery of their environment.

Ryff \& Keyes (1995) considered personal maturity through the concept of psychological well-being. The main indicator of psychological well-being is to have a purpose in life, which forms the intention and a sense of directedness, and thus gives meaning to human existence. L.A. Korostyleva (2005) also emphasizes that a person determines its life in the process of self-realization, giving it directedness, giving it the meaning of life and aspirations. The result is a transformation of the relationship of personality to the world, to others and to 
him under the influence of changes in their own philosophy of life, the image of the world. This approach directly emphasizes that personal development is through the development directedness of the personality.

W. Christensen (2004) believes that higher cognitive processes and knowledge play a key role in understanding and development directedness of the personality and personal maturity. This research emphasizes the importance to form a view of the world to carry out this process. In this view of the world should be fixed in the linguistic philosophy of life.

Thus, personal maturity - is the realization the general trend of human mental development, the capacity for continuous self-development and change while maintaining its uniqueness.

Previously, we found that personal maturity is a manifestation of directedness of the personality (Kalinina, Kovalevskaya, 2011) with the following properties: awareness, the level (social importance), the size, valence, efficacy, intensity, stability and time perspective. All of these properties characterize the orientation of the person in terms of qualitative and quantitative expressions.

Directedness of the personality - is a substructure of personality, with a complex, socially conditioned nature. This substructure determines the orientation of the individual to the stimuli, behaviors and environments that contribute to achieving long-term goals and self-congruency of the real selfimage and idealized self-image. (Kovalevskaya, 2009).

The results showed the importance of personal maturity of defectologist. Therefore it is necessary to begin to develop personal maturity of the specialist at the stage of learning in higher education. Based on the identified correlation between personal maturity and directedness of the personality, we hypothesized that the level of personal maturity of the subject can be enhanced through the development of the properties of personal directedness. To test this hypothesis we conducted a formative experiment, including practical training and exercises that allow interactivity and the ability to secure samples of the new way of thinking, patterns of behavior.

Conceptual model of the formative experiment has become a model describing the properties of Orientation of the personality in terms of V.A. Hansen (Figure 1). The model includes four parts: the information field directedness, temporary field directedness, the spatial field directedness and energy field directedness. Information field includes awareness and public profile directedness; temporary field - its stability and time perspective; spatial field - valence and the size; energy field - the efficiency and intensity of directedness.

The duration of the formative experiment was 40 hours. According to its results, we have made a program of socio-psychological training of the "Directedness of personality and way of life." 


\begin{tabular}{|l|l|}
\hline $\begin{array}{l}\text { Valence } \\
\text { (degree of } \\
\text { correlation of } \\
\text { meaningful } \\
\text { directednessl with } \\
\text { its other kinds) }\end{array}$ & $\begin{array}{l}\text { Size } \\
\text { (range of interests, } \\
\text { the number of } \\
\text { objects of focus) }\end{array}$ \\
\hline qualitative indicator & $\begin{array}{r}\text { quantitative } \\
\text { indicator }\end{array}$ \\
\hline
\end{tabular}

\begin{tabular}{|c|c|}
\hline 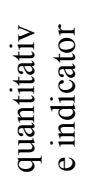 & Awareness \\
\hline 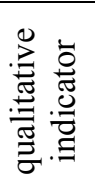 & $\begin{array}{l}\text { Level (social } \\
\text { importance } \\
\text { of } \\
\text { directedness) }\end{array}$ \\
\hline
\end{tabular}

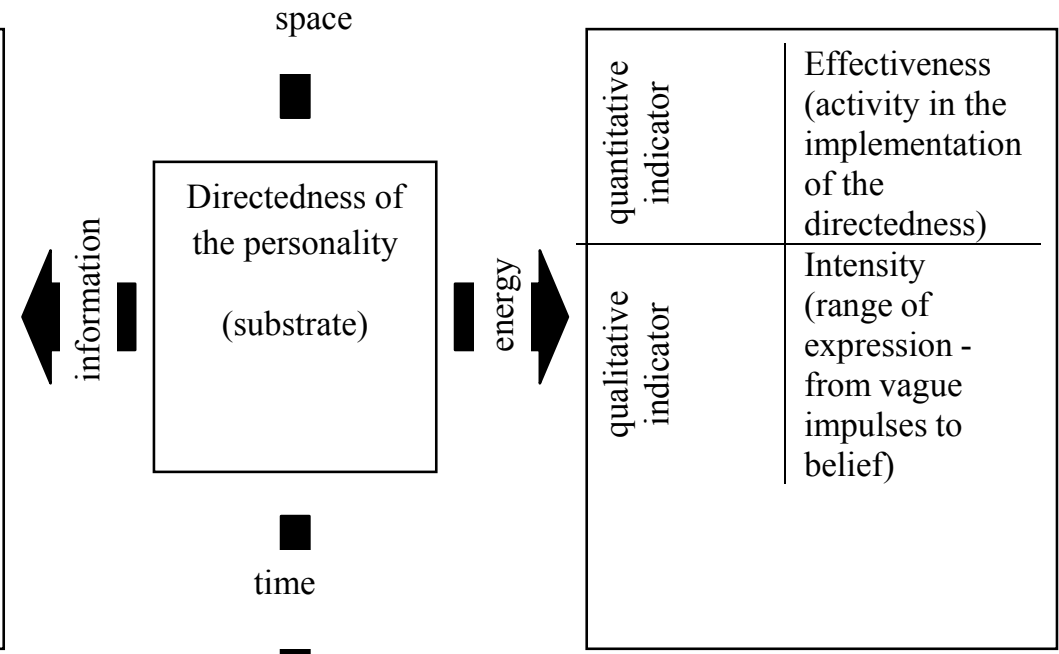

\begin{tabular}{|l|l|}
\hline \multicolumn{1}{|c|}{$\begin{array}{c}\text { qualitative } \\
\text { indicator }\end{array}$} & \multicolumn{1}{c|}{$\begin{array}{c}\text { quantitative } \\
\text { indicator }\end{array}$} \\
\hline $\begin{array}{l}\text { Stability } \\
\text { (duration and } \\
\text { stability of } \\
\text { meaning for life) }\end{array}$ & $\begin{array}{l}\text { time perspective } \\
\text { (In the future, the } \\
\text { past, to indefinitely) }\end{array}$ \\
\hline
\end{tabular}

Fig 1 Directedness of the personality properties

Students teaching specialties and specialties speech therapy Pskov State University participated in this experiment in the number of 36 people. 18 students were included in the experimental group. 17 students were included in the control group. 
To test the effectiveness of the formative experiment was conducted initial, recurrent and delayed measure the level of personal maturity (using a scale developed in the framework of the research) and applied the method of monitoring Manifestations students. Analysis of feedback and results of delayed diagnosis showed a positive change in the majority of students who participated in the experiment.

Note that students who were selected to participate in the experiment had a level of personal maturity is below average. Below are the results of repeated measurement.

1. In the control group, 62 percent of respondents had a level of personal maturity is below average. The level of personal maturity rose to an average of the 32 percent of respondents. 6 percent of the respondents had a level above the average. Note that we have interviewed the student (1 person), who had a level of personal maturity is above average. The purpose of the interview was to find out the possible reasons for this increase. The conversation showed that the life of the respondent have been major changes (separation from a loved one) that caused him to reconsider many of his views on life, to become more responsible and wiser.

2. In the experimental group, changes in the level of personal maturity were as follows: 54 percent of respondents had an increased level of personal maturity to a level above the average, 35 percent of respondents had an average level, the changes were not detected in 11 percent of the respondents (2 people).

Results of delayed diagnosis ( 3 months after the experiment):

1. In the control group, 58 percent of students had a level of personal maturity is below average, 30 percent of respondents had an average level, 12 percent of respondents had a level above the average.

2. In the experimental group, 72 percent of students had a level of personal maturity is above average, 28 percent of respondents had an average level of personal maturity

Thus, we have identified an important area of training for professionals working with children with special abilities. In this direction is to increase the personal maturity. Also found that personal maturity is a manifestation of directedness of the personality, which has developed properties. The preferred method of working with direction and as a result, personal maturity is the method of developing social and psychological training.

\section{Conclusions}

1. Special education teacher profession is an important and responsible activity and imposes special requirements not only professional, but also to the personal competence of a specialist. Among the most 
important personal qualities of a special teacher are the following: the desire for self-development, self-improvement, positive thinking, the activity, the desire for creativity, the ability to see and to use of their own capabilities, psychological independence, awareness of life's purpose and meaning, social interest, possession of a certain way of the world, philosophy of life, spontaneous behavior, a variety of interests. These qualities are the characteristics of personal maturity, which is an implementation of the general trend of human mental development, the capacity for continuous self-development and change while maintaining its uniqueness.

2. Personal maturity is a manifestation of directedness of the personality with the following properties: awareness, the level (social importance), the size, valence, effectiveness, intensity, stability, and time perspective. All of these properties characterize the directedness of the personality, from the perspective of the qualitative and quantitative implications.

3. The development of personal maturity special educator must be implemented in conditions of the educational environment of higher education institution by forming orientation of the personality properties. The preferred method of work is to develop the socialpsychological training.

\section{Summary}

Psychological support for children with special health abilities imposes certain requirements for the competence of the special education teacher. Of course, the specialist must possess the professional skills and continually improve them. But defectologist should have personal competence. Personal Competence includes characteristics that are the basis of humanistic attitude to children and is a measure of personal maturity.

On this basis, the development of a professional in the field of special psychology should be directed to the formation of such personal characteristics as motivation for self-improvement, positive thinking, the activity, the desire for self-fulfillment in the creation and use of creativity when working with children. All of these features are included in the directedness of the personality. Therefore defectologist must realize and achieve their life goals, values, needs and aspirations, beliefs, etc. for the successful and effective implementation of the professional activity. These characteristics are indicative of personal maturity, which is a manifestation of conscious and formed directedness of the personality.

Thus, personal maturity is an indispensable to the successful and effective implementation of professional specialists who work with children with special abilities. It is a condition of creating a positive and tolerant attitude to these children, 
and to create a basis for the development and deployment best methods and ways of development activity.

\section{Bibliography}

1. Christensen, W. (2004). Self-directedness, integration and higher cognition. Slightly modified version of a paper that appeared in Language Sciences 26(6): 661-692. P.

2. Galinsky, A., William, W. Maddux. (2009). Cultural Borders and Mental Barriers: The Relationship Between Living Abroad and Creativity. Journal of Personality and Social Psychology, Vol. 96, No. 5, 1047-1061.P.

3. Ryff, C. D., \& Keyes, C. L. M. (I995). The structure of psychological well-being revisited. Journal of Personal and Social Psychology, 69, 719-727.P.

4. Калинина, Р.P., Ковалевская, Е.В. (2011). Повышение личностной зрелости как направление подготовки специалистов по работе с детьми с особыми потребностями. «Нарушения психического развития у детей - междисциплинарная проблема»: материаль всероссийской научно-практической конференщии, 1-2 декабря, 2011.:Смоленск, СмолГУ. С.89-91.Стр.

5. Ковалевская, Е.В. (2009). Теоретические проблемы исследования направленности личности. Психология XXI века. Сборник материалов международной научно практической конференции молодых ученых. Санкт-петербург. С. 83-87

6. Олпорт, Г. (2002). Становление личности: избр. тр. / Под общ. ред. Д.А. Леонтьева. - М.: Смысл.

7. Реан, А.А. (2002). Самоактуализащия и самотрансценденция личности. Психология личности в трудах отечественных психологов/Сост. Л.В. Куликов. СПб.

8. Сергиенко, Е.А. (2007). Зрелость: молярный или модулярный подход? Феномен и категория зрелости в психологии / отв. ред. А.Л. Журавлев, Е.А. Сергиенко. - М.: издательство «Институт психологии РАН». 223с.

9. Харламенкова, Н.Е. (2007). Спонтанность и контроль в зрелых личностных отношениях. Феномен и категория зрелости в психологии / отв. ред. А.Л. Журавлев, Е.А. Сергиенко. - М.: Издательство «Институт психологии РАН». 223c.

\begin{tabular}{|r|l|}
\hline Ekaterina Kovalevskaya, \\
Senior Lecturer & $\begin{array}{l}\text { Department of General and } \\
\text { Social Psychology Pskov State } \\
\text { University } \\
\text { Email: summereal@gmail.com }\end{array}$ \\
\hline
\end{tabular}

